\title{
PENGARUH PEMBERIAN LABU SIAM BERIMPLIKASI TERHADAP TEKANAN DARAH IBU HAMIL DENGAN HIPERTENSI DI WILAYAH KERJA UPTD PUSKESMAS MAJA KABUPATEN MAJALENGKA
}

\author{
${ }^{1}$ Yuyun Wahyu Indah Indriyani, ${ }^{2}$ Gita Mutiarani Komala \\ ${ }^{1,2}$ Sekolah Tinggi Ilmu Kesehatan YPIB Majalengka \\ indah.yani08@gmail.com
}

\begin{abstract}
Abstrak
Hipertensi dalam kehamilan adalah hipertensi yang terjadi saat kehamilan berlangsung dan biasanya pada bulan terakhir kehamilan. UPTD Puskesmas Maja merupakan puskesmas di Kabupaten Majalengka dengan persentase hipertensi paling tinggi yaitu sebesar 83,94\%. Penelitian ini bertujuan untuk mengetahui pengaruh pemberian labu siam terhadap tekanan darah ibu hamil dengan hipertensi di Wilayah Kerja UPTD Puskesmas Maja Kabupaten Majalengka tahun 2020. Jenis penelitian pre eksperiment dengan one group pretest-posttest design. Sampel dalam penelitian ini adalah 30 ibu hamil yang mengalami hipertensi di Wilayah Kerja UPTD Puskesmas Maja Kabupaten Majalengka dan dibagi menjadi dua kelompok yaitu 15 kelompok eksperimen dan 15 kelompok kontrol. Analisis univariat menggunakan distribusi tendensi sentral dan analisis bivariatnya menggunakan Wilcoxon test. Hasil penelitian menunjukkan bahwa rata-rata tekanan darah sistolik ibu hamil dengan hipertensi sebelum pemberian labu siam sebesar 148,33 dan rata-rata tekanan darah diastolik sebelum perlakuan sebesar 98,00 mmHg dan sesudah pemberian labu siam sebesar 125,67 mmHg. Kesimpulan ada pengaruh pemberian labu siam terhadap tekanan darah ibu hamil dengan hipertensi di Wilayah Kerja UPTD Puskesmas Maja Kabupaten Majalengka tahun 2020.
\end{abstract}

\section{Kata Kunci $\quad$ : Labu Siam, Tekanan Darah, Hipertensi}

\section{Pendahuluan}

Kesehatan dan kesejahteraan ibu merupakan unsur utama dalam menentukan generasi yang akan datang. Proses kehamilan, persalinan dan bayi yang dilahirkan harus aman dan sehat serta membawa kebahagian bagi ibu dan keluarga. Semua ibu mempunyai hak untuk kesempatan mendapatkan proses kehamilan yang aman sampai saat melahirkan dan juga 
JOURNAL OF MIDWIFERY CARE :

VOL. 01 NO. 01, DESEMBER 2020

DOI:10.34305/jmc.v1i1.191
Ciptaan disebarluaskan di bawah Lisensi Creative Commons AtribusiNonKomersial-BerbagiSerupa 4.0 Internasional. hak untuk mempunyai bayi yang lahir sehat (Lailiyana 2017)

Menjaga dan memelihara kesehatan ibu mulai dari kehamilan, persalinan dan nifas merupakan prioritas dalam pelayanan kebidanan. Salah satu penyakit pada kehamilan yang mendapat perhatian dunia adalah hipertensi dalam kehamilan (Kemenkes 2019). Menurut data WHO (2018), angka kejadian hipertensi dalam kehamilan di seluruh dunia berkisar antara 0,51\%-38,4\%. Di negara berkembang, angka kejadian hipertensi dalam kehamilan berkisar antara 5-6\%. Secara global, $80 \%$ kematian ibu hamil yang tergolong dalam penyebab kematian ibu secara langsung, disebabkan karena perdarahan pasca persalinan $(25 \%)$, hipertensi pada ibu hamil (12\%), partus macet (8\%), aborsi (13\%) dan karena sebab lain (7\%) (WHO 2018).

Angka Kematian Ibu (AKI) di Indonesia saat ini masih tinggi yaitu 305 per 100.000 kelahiran hidup dan target AKI Indonesia pada tahun 2030 adalah 131 per 100.000 kelahiran hidup (Kemenkes 2019). Adapun AKI di Provinsi Jawa Barat pada tahun 2018 sebanyak 823 orang $(0,08 \%)$ dari jumlah ibu hamil sebanyak 971.458 orang (Dinas Kesehatan Provinsi Jawa Barat 2019).
Jumlah kematian ibu di Kabupaten Majalengka pada tahun 2018 sebanyak 16 kasus yang terdiri dari kematian ibu hamil mencapai 3 kasus $(18,7 \%)$, melahirkan sebanyak 6 kasus (37,5\%), dan ibu nifas sebanyak 7 kasus (43,7\%). Penyebabnya diantaranya adalah hipertensi dalam kehamilan sebanyak 8 kasus (50\%), perdarahan sebanyak 6 kasus $(37,5 \%)$, jantung sebanyak 1 kasus $(6,25 \%)$, dan lainlain 1 kasus $(6,25 \%)$ (Dinas Kesehatan Kabupaten Majalengka 2019).

Hipertensi pada ibu hamil merupakan salah satu penyebab kematian ibu yang utama, maka dari itu perlu dilakukan upaya pencegahan dan penanganan. Berdasarkan data Dinas Kesehatan Kabupaten Majalengka tahun 2018, jumlah kasus hipertensi pada ibu hamil sebanyak 1.616 kasus $(7,8 \%)$ dari jumlah ibu hamil sebanyak 21.020 orang. Adapun puskesmas dengan jumlah kasus hipertensi pada ibu hamil tertinggi terdapat di UPTD Puskesmas Maja yaitu sebanyak 108 kasus $(12,3 \%)$ dari jumlah ibu hamil sebanyak 873 orang. Sedangkan pada tahun 2017, jumlah kasus hipertensi pada ibu hamil sebanyak 87 kasus $(11,4 \%)$ dari 761 orang atau ada kenaikan sebesar 0,9 (Dinas Kesehatan Kabupaten Majalengka 2019) 
JOURNAL OF MIDWIFERY CARE :

VOL. 01 NO. 01, DESEMBER 2020

DOI:10.34305/jmc.v1i1.191
Ciptaan disebarluaskan di bawah Lisensi Creative Commons AtribusiNonKomersial-BerbagiSerupa 4.0 Internasional.
Banyaknya angka kejadian hipertensi hal ini perlu dicegah karena hipertensi dapat menyebabkan angka kematian. Hipertensi dalam kehamilan adalah hipertensi yang terjadi saat kehamilan berlangsung dan biasanya pada bulan terakhir kehamilan atau lebih setelah 20 minggu usia kehamilan pada wanita yang sebelumnya normotensif, tekanan darah mencapai nilai 140/90 $\mathrm{mmHg}$, atau kenaikan tekanan sistolik $30 \mathrm{mmHg}$ dan tekanan diastolik $15 \mathrm{mmHg}$ di atas nilai normal (Junaidi 2015).

Dampak mikro yang ditimbulkan hipertensi pada kehamilan antara lain bisa pada ibu dan janin. Pada ibu dapat terjadi iskemia uteri plasenta, spasme arteriolar, kejang dan koma, pneumonia, infeksi saluran kemih, kelebihan cairan dan pada janin janin dapat mengalami Intra Uterine Growth

Restriction

(IUGR), oligohidramnion, prematuritas. Sedangkan dampak makro yang dapat ditimbulkan adalah angka kematian ibu dan bayi meningkat (Saifuddin 2016)

Faktor penyebab hipertensi secara pasti tidak diketahui tetapi dimungkinkan faktor resiko hipertensi kehamilan diantaranya adalah pengetahuan, pola makan, paritas, umur, riwayat hipertensi, sosial ekonomi dan obesitas (Sundari 2016).
Sementara menurut Prawirohardjo (2016), penyebab hipertensi dalam kehamilan umumnya adalah pola makan dan gaya hidup yang tidak sehat. Pola makan meliputi menu makanan, cara memasak, cara konsumsi serta membuat kombinasi yang sehat dan sesuai setiap jam makan 'besar'.

Terdapat dua jenis terapi hipertensi yaitu dengan farmakologis (medis) dan non farmakologis (herbal). Terapi non farmakologis adalah suatu pengobatan dengan tidak diberikan obat, yaitu dengan olahraga, mengurangi konsumsi rokok dan alkohol, dan diet sayuran atau buah, salah satunya dengan menggunakan labu siam. Labu siam merupakan sayuran yang tumbuh pada subtropis selain sebagai makanan juga digunakan sebagai obat. Labu siam banyak dikonsumsi masyarakat karena harganya cukup murah serta rasanya enak dan dingin (Saifuddin, 2016 dan Brevik, dalam (Jayani 2016)).

Salah satu makanan yang dapat membantu penurunan hipertensi yaitu labu siam. Labu siam mengandung berbagai macam nutrisi dan anti inflamasi sehingga dapat mengobati tekanan darah tinggi. Kandungan dalam labu siam diketahui memiliki efek diuretik sehingga menurunkan kadar garam di dalam darah melalui ekskresi urin. Dengan berkurangnya 
JOURNAL OF MIDWIFERY CARE :

VOL. 01 NO. 01, DESEMBER 2020

DOI:10.34305/jmc.v1i1.191
Ciptaan disebarluaskan di bawah Lisensi Creative Commons AtribusiNonKomersial-BerbagiSerupa 4.0 Internasional. kadar garam yang bersifat menyerap atau menahan air ini akan meringankan kerja jantung dalam memompa darah sehingga tekanan darah akan menurun (Elisabeth 2015).

Labu siam mengandung 90 persen air, 7,5 persen karbohidrat, 1 persen protein, 0,6 persen serat, 0,2 persen abu, dan 0,1 persen lemak. Juga mengandung sekitar 20 mg kalsium, $25 \mathrm{mg}$ fosfor, $100 \mathrm{mg}$ kalium, 0,3 $\mathrm{mg}$ zat besi, $2 \mathrm{mg}$ natrium, serta beberapa zat kimia yang berkhasiat obat. Disamping itu labu siam mengandung kandungan alkaloid yang dapat membuka pembuluh darah yang tersumbat sehingga labu siam dapat digunakan untuk menurunkan tekanan darah tinggi (Zakiah 2012)

Labu siam merupakan sayuran penurun kolesterol, pencegah hipertensi, bagus sebagai sumber nutrisi ibu hamil dan menyusui, baik untuk penderita asam urat, diabetes dan penderita sariawan, serta menjaga kesehatan ginjal, serta sayuran ini mudah didapat dan murah di pasaran (Elisabeth 2015). Labu siam dikonsumsi langsung dengan cara dikukus dapat menurunkan tekanan darah pada ibu hamil jika dikonsumsi setiap hari selama seminggu dengan dosis sebanyak 250 gram (Jayani 2016)
Pada penelitian ini menggunakan labu siam untuk menurunkan hipertensi pada pada ibu hamil primigravida dengan hipertensi < 20 minggu, hal ini karena ibu hamil primigravida ibu belum memahami mengenai hipertensi dan cara pencegahannya, dan labu siam merupakan salah satu cara alternatif yang aman untuk menurunkan hipertensi. Hasil studi pendahuluan di UPTD Puskesmas Maja pada tanggal 20 Januari 2020, terhadap $5 \mathrm{ibu}$ hamil hipertensi didapatkan bahwa semuanya ibu hanya mengkonsumsi obat anti hipertensi yang diberikan oleh petugas kesehatan dan belum mengatasinya secara non farmakologis seperti mengkonsumsi labu siam dengan cara dikukus dan dimakan. Oleh karena itu peneliti tertarik melakukan penelitian tentang pengaruh pemberian Labu siam terhadap tekanan darah ibu hamil dengan hipertensi.

\section{Metode}

Jenis penelitian pre eksperiment dengan one group pretest-posttest design. Sampel dalam penelitian ini adalah $30 \mathrm{ibu}$ hamil yang mengalami hipertensi di Wilayah Kerja UPTD Puskesmas Maja Kabupaten Majalengka dan dibagi menjadi dua kelompok yaitu 15 kelompok eksperimen dan 15 kelompok kontrol. Analisis univariat 
JOURNAL OF MIDWIFERY CARE :

VOL. 01 NO. 01, DESEMBER 2020

DOI: $\underline{10.34305 / j m c . v 1 i 1.191}$
Ciptaan disebarluaskan di bawah Lisensi Creative Commons AtribusiNonKomersial-BerbagiSerupa 4.0 Internasional.

menggunakan distribusi tendensi sentral dan

analisis bivariatnya menggunakan Wilcoxon

test.

Hasil

Tabel 1. Distribusi Tendensi Sentral Tekanan Darah Ibu Hamil dengan Hipertensi Sebelum Pemberian Labu Siam

\begin{tabular}{lcccc}
\hline Tekanan Darah & $\begin{array}{c}\text { Mean } \\
\text { Median }\end{array}$ & S.D & $\begin{array}{c}\text { Minimal- } \\
\text { Maksimal }\end{array}$ & 95\% CI \\
\hline Sistolik sebelum perlakuan & 148,33 & 5,876 & $140-160$ & $145,08-151,59$ \\
Diastolik sebelum perlakuan & 145,00 & & & \\
& 98,00 & 7,512 & $90-110$ & $93,84-102,16$ \\
\hline
\end{tabular}

Berdasarkan tabel 1 menunjukkan bahwa rata-rata tekanan darah sistolik sebelum perlakuan sebesar $148,33 \mathrm{mmHg}$ dengan mediannya $145,00 \mathrm{mmHg}$, standar deviasi nya 5,876. Tekanan darah sistolik sebelum perlakuan minimal $140 \mathrm{mmHg}$ dan maksimal $160 \mathrm{mmHg}$, dan berdasarkan nilai 95\%CI diyakini bahwa tekanan darah sistolik ibu hamil dengan hipertensi sebelum pemberian labu siam di Wilayah Kerja UPTD Puskesmas Maja Kabupaten Majalengka tahun 2020 berada antara
145,08-151,59. Sementara rata-rata tekanan darah diastolik sebelum perlakuan sebesar 98,00 $\mathrm{mmHg}$ dengan mediannya 100,00 $\mathrm{mmHg}$, standar deviasinya 7,512. Tekanan darah diastolik sebelum perlakuan minimal $90 \mathrm{mmHg}$ dan maksimal $110 \mathrm{mmHg}$, dan berdasarkan nilai 95\%CI diyakini bahwa tekanan darah diastolik ibu hamil dengan hipertensi sebelum pemberian labu siam di Wilayah Kerja UPTD Puskesmas Maja Kabupaten Majalengka tahun 2020 berada antara 93,84-102,16.

Tabel 2. Distribusi Tendensi Sentral Tekanan Darah Ibu Hamil dengan Hipertensi Sesudah Pemberian Labu Siam

\begin{tabular}{|c|c|c|c|c|}
\hline $\begin{array}{c}\text { Tekanan Darah Ibu Hamil } \\
\text { dengan Hipertensi }\end{array}$ & $\begin{array}{c}\text { Mean } \\
\text { Median }\end{array}$ & S.D & $\begin{array}{l}\text { Minimal- } \\
\text { Maksimal }\end{array}$ & $95 \% \mathrm{CI}$ \\
\hline Sistolik sesudah perlakuan & $\begin{array}{l}125,67 \\
120,00\end{array}$ & 9,796 & $110-140$ & $120,24-131,09$ \\
\hline Diastolik sesudah perlakuan & $\begin{array}{l}92,00 \\
90,00\end{array}$ & 3,684 & $90-100$ & $89,96-94,04$ \\
\hline
\end{tabular}

Berdasarkan tabel 2, menunjukkan bahwa rata-rata tekanan darah sistolik sesudah perlakuan sebesar $125,67 \mathrm{mmHg}$ dengan mediannya $120,00 \mathrm{mmHg}$, standar 
JOURNAL OF MIDWIFERY CARE :

VOL. 01 NO. 01, DESEMBER 2020

DOI:10.34305/jmc.v1i1.191
Ciptaan disebarluaskan di bawah Lisensi Creative Commons AtribusiNonKomersial-BerbagiSerupa 4.0 Internasional. deviasi nya 9,796. Tekanan darah sistolik sesudah perlakuan minimal $110 \mathrm{mmHg}$ dan maksimal $140 \mathrm{mmHg}$, dan berdasarkan nilai 95\%CI diyakini bahwa tekanan darah sistolik ibu hamil dengan hipertensi sesudah pemberian labu siam di Wilayah Kerja UPTD Puskesmas Maja Kabupaten Majalengka tahun 2020 berada antara 120,24-131,09. Sementara rata-rata tekanan darah diastolik sesudah perlakuan sebesar 92,00 $\mathrm{mmHg}$ dengan mediannya 90,00 mmHg, standar deviasinya 3,684. Tekanan darah diastolik sesudah perlakuan minimal
$90 \mathrm{mmHg}$ dan maksimal $100 \mathrm{mmHg}$, dan berdasarkan nilai 95\%CI diyakini bahwa tekanan darah diastolik ibu hamil dengan hipertensi sesudah pemberian labu siam di Wilayah Kerja UPTD Puskesmas Maja Kabupaten Majalengka tahun 2020 berada antara 89,96-94,04.

Uji normalitas pada penelitian ini menggunakan uji Shapiro Wilk, hal ini karena jumlah respondennya kurang dari 50. Keputusan ujinya yaitu jika nilai $\mathrm{p}>0,05$ maka data dinyatakan normal dan jika $\mathrm{p}<$ 0,05 maka data dinyatakan tidak normal.

Tabel 3. Uji Normalitas dengan Saphiro Wilk

\begin{tabular}{lccc}
\hline \multicolumn{1}{c}{ Tekanan Darah Ibu Hamil dengan Hipertensi } & \multicolumn{3}{c}{ Shapiro-Wilk } \\
\cline { 2 - 4 } & Statistic & Df & Sig. \\
\hline Sistolik (sebelum perlakuan) & 0.910 & 15 & 0.133 \\
Diastolik (sebelum perlakuan) & 0.842 & 15 & 0.013 \\
Sistolik (sesudah perlakuan) & 0.905 & 15 & 0.114 \\
Diastolik (sesudah perlakuan) & 0.596 & 15 & 0.000 \\
\hline
\end{tabular}

Berdasarkan tabel 3, hasil uji normalitas dengan Saphiro wilk, menunjukkan bahwa data tekanan darah ibu hamil dengan hipertensi untuk sistolik (sebelum perlakuan) diperoleh nilai $\mathrm{p}=$ 0,133 dan data sistolik (sesudah perlakuan) diperoleh nilai $\mathrm{p}=0,114$, dengan demikian maka data ini termasuk normal. Namun, data tekanan darah ibu hamil dengan hipertensi untuk diastolik (sebelum perlakuan) diperoleh nilai $\mathrm{p}=0,013$ dan data diastolik (sesudah perlakuan) diperoleh nilai $\mathrm{p}=$ 0,000 yang artinya data ini tidak normal. Dengan demikian maka uji yang digunakan untuk data sistolik menggunakan uji $\mathrm{t}$ berpasangan dan untuk diastolik uji wilcoxon. 
JOURNAL OF MIDWIFERY CARE :

VOL. 01 NO. 01, DESEMBER 2020

DOI:10.34305/jmc.v1i1.191
Ciptaan disebarluaskan di bawah

Lisensi Creative Commons Atribusi-

NonKomersial-BerbagiSerupa 4.0

Internasional.

Tabel 4. Pengaruh Pemberian Labu Siam terhadap Tekanan Darah Sistolik Ibu Hamil dengan Hipertensi

\begin{tabular}{cccccc}
\hline Tekanan Darah Sistolik & Mean & Beda Mean & N & t & P value \\
\hline Sebelum perlakuan & 148.33 & 22,66 & 15 & 8.500 & 0.000 \\
Sesudah perlakuan & 125.67 & & & \\
\hline
\end{tabular}

Tabel diatas menunjukkan bahwa rata-rata tekanan sistolik sebelum perlakuan sebesar 148,33 mmHg dan rata-rata tekanan sistolik sesudah perlakuan sebesar 125,67 $\mathrm{mmHg}$ artinya terdapat selisih sebesar 22,66. Perbedaan ini menunjukkan bahwa labu

Tabel 5. Pengaruh Pemberian Labu Siam terhadap Tekanan Darah Diastolik Ibu Hamil dengan Hipertensi

\begin{tabular}{cc}
\hline $\begin{array}{c}\text { Tekanan Darah Diastolik Sebelum dan Sesudah } \\
\text { Perlakuan }\end{array}$ & Diastole Pretest - Diastol Posttest \\
\hline Z & $-2.774^{\mathrm{b}}$ \\
Asymp. Sig. (2-tailed) & .006 \\
\hline
\end{tabular}

Berdasarkan tabel 5, hasil uji Wilcoxon diperoleh nilai $\mathrm{p}=0,006$ yang artinya bahwa ada pengaruh pemberian labu siam terhadap tekanan darah diastolik ibu hamil dengan hipertensi di wilayah kerja UPTD Puskesmas Maja Kabupaten Majalengka tahun 2020.

\section{Pembahasan}

Hasil penelitian menunjukkan bahwa rata-rata tekanan darah sistolik ibu hamil dengan hipertensi sebelum pemberian labu siam di Wilayah Kerja UPTD Puskesmas Maja Kabupaten Majalengka tahun 2020 sebesar 148,33 dan rata-rata tekanan darah siam mempunyai pengaruh terhadap tekanan sistolik, sesuai dengan hasil uji t berpasangan dengan nilai $p=0,000$. Adapun uji Wilcoxon untuk data diastolik sebagai berikut: 
JOURNAL OF MIDWIFERY CARE :

VOL. 01 NO. 01, DESEMBER 2020

DOI:10.34305/jmc.v1i1.191
Ciptaan disebarluaskan di bawah Lisensi Creative Commons AtribusiNonKomersial-BerbagiSerupa 4.0 Internasional. mereka punya kebun sayuran sendiri. Sehingga untuk membiasakan penderita hipertensi di daerah Maja dengan mengkonsumsi labu tidak sulit.

Hipertensi dalam kehamilan adalah hipertensi yang terjadi saat kehamilan berlangsung dan biasanya pada bulan terakhir kehamilan atau lebih setelah 20 minggu usia kehamilan pada wanita yang sebelumnya normotensif, tekanan darah mencapai nilai 140/90 $\mathrm{mmHg}$, atau kenaikan tekanan sistolik $30 \mathrm{mmHg}$ dan tekanan diastolik $15 \mathrm{mmHg}$ di atas nilai normal (Junaidi 2015).

Dampak mikro yang ditimbulkan akibat hipertensi pada kehamilan antara lain bisa pada ibu dan janin. Pada ibu dapat terjadi iskemia uteri plasenta, spasme arteriolar, kejang dan koma, pneumonia, infeksi saluran kemih, kelebihan cairan dan pada janin janin dapat mengalami Intra Uterine Growth Restriction (IUGR), oligohidramnion, prematuritas. Sedangkan dampak makro yang dapat ditimbulkan adalah angka kematian ibu dan bayi meningkat (Saifuddin 2016).

Faktor penyebab hipertensi secara pasti tidak diketahui tetapi dimungkinkan faktor resiko hipertensi kehamilan diantaranya adalah pengetahuan, pola makan, paritas, umur, riwayat hipertensi, sosial ekonomi dan obesitas (Sundari 2016). Sementara menurut Prawirohardjo (2016), penyebab hipertensi dalam kehamilan umumnya adalah pola makan dan gaya hidup yang tidak sehat. Pola makan meliputi menu makanan, cara memasak, cara konsumsi serta membuat kombinasi yang sehat dan sesuai setiap jam makan 'besar'.

Hasil penelitian ini sejalan dengan hasil penelitian Safitri (2016) pada ibu hamil dengan hipertensi di Wilayah Kerja Puskesmas Cimalaka Kabupaten Sumedang" menunjukkan rata-rata tekanan darah sistolik ibu hamil dengan hipertensi sebelum pemberian labu siam sebesar 150,00 dan rata-rata tekanan darah diastolik sebelum perlakuan sebesar 100,00 $\mathrm{mmHg}$. Juga sejalan dengan hasil penelitian Jayani (2016) di Wilayah Kerja Puskesmas Wonorejo Kecamatan Ngadiluwih Kabupaten Kediri menunjukkan bahwa ratarata tekanan darah sistolik ibu hamil dengan hipertensi sebelum pemberian labu siam sebesar 155,00 dan rata-rata tekanan darah diastolik sebelum perlakuan sebesar 95,00 $\mathrm{mmHg}$.

Selanjutnya rata-rata tekanan darah sistolik ibu hamil dengan hipertensi sesudah pemberian labu siam di Wilayah Kerja UPTD Puskesmas Maja Kabupaten Majalengka tahun 2020 sebesar 125,67 
JOURNAL OF MIDWIFERY CARE :

VOL. 01 NO. 01, DESEMBER 2020

DOI:10.34305/jmc.v1i1.191
Ciptaan disebarluaskan di bawah Lisensi Creative Commons AtribusiNonKomersial-BerbagiSerupa 4.0 Internasional.
$\mathrm{mmHg}$ dan rata-rata tekanan darah diastolik sesudah perlakuan sebesar 92,00 $\mathrm{mmHg}$. Menurunya tekanan darah pada ibu hamil yang mengalami hipertensi karena ibu hamil secara teratur mengkonsumsi labu siam selama seminggu akibatnya tekanan darah dapat menurun.

Terapi non farmakologis untuk hipertensi adalah suatu pengobatan dengan tidak diberikan obat, yaitu dengan olahraga, mengurangi konsumsi rokok dan alkohol, dan diet sayuran atau buah, salah satunya dengan menggunakan labu siam. Labu siam merupakan sayuran yang tumbuh pada subtropis selain sebagai makanan juga digunakan sebagai obat. Labu siam banyak dikonsumsi masyarakat karena harganya cukup murah serta rasanya enak dan dingin (Saifuddin, 2016 dan Brevik, dalam (Jayani 2016)).

Labu siam mengandung kalium dan alkaloid yang bersifat diuretik yaitu membantu ginjal mengeluarkan kelebihan cairan dan garam dari tubuh, sehingga berkurangnya cairan dalam darah akan menurunkan tekanan darah. Khasiat diuretik ini akan berdampak pada penurunan tekanan darah tinggi (hipertensi), mencegah pengerasan dan pengapuran pembuluh arteri, mengurangi kemungkinan serangan jantung dan melarutkan batu ginjal (Sudibyo 2014).
Hasil penelitian ini sejalan dengan hasil penelitian Mayangsari (2016) di Puskesmas Cimalaka Sumedang menunjukkan bahwa rata-rata tekanan darah sistolik ibu hamil dengan hipertensi sesudah pemberian labu siam sebesar $115,00 \mathrm{mmHg}$ dan rata-rata tekanan darah diastolik sesudah perlakuan sebesar 90,00 mmHg. Penelitian ini juga sesuai dengan teori bahwa terdapat dua jenis terapi hipertensi yaitu dengan farmakologis (medis) dan non farmakologis (herbal). Terapi non farmakologis adalah suatu pengobatan dengan tidak diberikan obat, yaitu dengan olahraga, mengurangi konsumsi rokok dan alkohol, dan diet sayuran atau buah, salah satunya dengan menggunakan labu siam. Labu siam merupakan sayuran yang tumbuh pada subtropis selain sebagai makanan juga digunakan sebagai obat. Labu siam banyak dikonsumsi masyarakat karena harganya cukup murah serta rasanya enak dan dingin (Saifuddin, 2016 dan Brevik, dalam (Jayani 2016)).

Hasil penelitian ini sejalan dengan teori bahwa manfaat labu siam yang pertama dan paling terkenal adalah membantu menurunkan tekanan darah. Konsumsi labu siam secara rutin oleh penderita hipertensi dipercaya dapat menurunkan tekanan darah. Efek diuretik dan kandungan antioksidan 
JOURNAL OF MIDWIFERY CARE :

VOL. 01 NO. 01, DESEMBER 2020

DOI:10.34305/jmc.v1i1.191
Ciptaan disebarluaskan di bawah Lisensi Creative Commons AtribusiNonKomersial-BerbagiSerupa 4.0 Internasional. dalam labu siam adalah yang memiliki peran dalam penurunan tekanan darah (Putri n.d.)

Hasil penelitian ini sejalan dengan teori bahwa salah satu makanan yang dapat membantu penurunan hipertensi yaitu labu siam. Labu siam mengandung berbagai macam nutrisi dan anti inflamasi sehingga dapat mengobati tekanan darah tinggi. Kandungan kalium dalam labu siam diketahui memiliki efek diuretik sehingga dapat menurunkan kadar garam dalam darah melalui ekskresi urin. Dengan berkurangnya kadar garam yang bersifat menyerap atau menahan air ini akan meringankan kerja jantung dalam memompa darah sehingga tekanan darah akan menurun (Elisabeth 2015). Terbukti dari hasil beberapa penelitian pemberian labu siam dalam bentuk jus maupun langsung dimakan dapat menurunkan tekanan darah (Fauziah, Hidajati, and Soejoenoes 2019).

Demikian juga dengan hasil penelitian Sulastri (2016) di Puskesmas Balongan Indramayu menunjukkan bahwa pemberian labu siam efektif menurunkan tekanan darah hipertensi pada wanita $(\rho=$ $0,001)$.

\section{Kesimpulan}

Pemberian labu siam dapat menurunkan tekanan darah sistolik dan diastolik ibu hamil dengan hipertensi. Rata-rata tekanan darah sistolik ibu hamil dengan hipertensi sebelum pemberian labu siam 148/98 mmHg menurun menjadi $125 / 92 \mathrm{mmHg}$ setelah pemberian labu siam.

\section{Saran}

Pada penelitian ini terbukti bahwa ada pengaruh pemberian labu siam terhadap tekanan darah ibu hamil dengan hipertensi maka petugas kesehatan perlu memberikan penyuluhan kepada ibu hamil tentang hipertensi pada kehamilan dengan bahasa yang mudah dipahami, juga tentang cara alternatif menurunkan tekanan darah yaitu dengan mengkonsumsi labu siam dengan contoh pembuatan labu siam yang baik dan benar.

\section{Daftar Pustaka}

Dinas Kesehatan Provinsi Jawa barat. 2019. Derajat Kesehatan Provinsi Jawa Barat Tahun 2018. Bandung: Dinas Kesehatan Provinsi Jawa Barat.

Dinas Kesehatan Kabupaten Majalengka. 2019. Profil Kesehatan Kabupaten Majalengka Tahun 2018. Majalengka.

Elisabeth. 2015. "Pemberian Labu Siam Berimplikasi Terhadap Perubahan Tekanan Darah Ibu Hamil Preeklampsi." Jurnal Care 2:38.

Fauziah, Nur Alfi, Kamilah Hidajati, and Ariawan Soejoenoes. 2019. "The Effect

E-ISSN 2774-4167 | 31 
JOURNAL OF MIDWIFERY CARE :

VOL. 01 NO. 01, DESEMBER 2020

DOI: $\underline{10.34305 / j m c . v 1 i 1.191}$

of Chayote Extract (Sechium Edule) On Blood Pressure in Pregnant Women with Hypertension." Indonesian Journal of Medicine 4(3):266-77.

Jayani, Indah. 2016. "Pemberian Labu Siam Berimplikasi Terhadap Perubahan Tekanan Darah Ibu Hamil Hipertensi." Care: Jurnal Ilmiah Ilmu Kesehatan 4(2):36-44.

Junaidi, Iskandar. 2015. "Hipertensi, Pengenalan, Pencegahan, Dan Pengobatan." Jakarta: PT Bhuana Ilmu Populer.

Kemenkes, R. I. 2019. "Survei Demografi AKI Dan AKB." Jakarta: Kementrian Kesehatan Republik Indonesia.

Lailiyana. 2017. Patologi Kebidanan Cetakan 2. Yogyakarta: Nuha Medika.

Mayangsari. 2016. "Pengaruh Pemberian Labu Siam Terhadap Hipertensi Pada Ibu Hamil Primigravida Di Puskesmas Cimalaka Sumedang." Jurnal Ilmu Keperawatan (2).

Prawirohardjo, Sarwono. 2016. "Buku Acuan Nasional Pelayanan Kesehatan Maternal Dan Neonatal." Jakarta: Yayasan Bina Pustaka Sarwono Prawirohardjo.

Putri. n.d. "Jenis Tanaman Keluarga." Diakses Tanggal 23 Januari 2020. Retrieved (media.neliti.com).
Ciptaan disebarluaskan di bawah Lisensi Creative Commons AtribusiNonKomersial-BerbagiSerupa 4.0 Internasional.

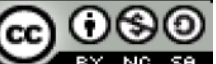

Safitri. 2016. "Pengaruh Pemberian Labu Siam Terhadap Tekanan Darah Ibu Hamil Dengan Hipertensi Di Wilayah Kerja Puskesmas Cimalaka Kabupaten Sumedang." Naskah Publikasi Jurnal Medika 2016.

Saifuddin, Abdul Bari. 2016. "Buku Ajar Patologi Obstetri Untuk Mahasiswa Kebidanan.” Jakarta: Rineka Cipta.

Sudibyo, Arvin. 2014. "Efek Jus Buah Labu Siam (Sechium Edule Swartz.) Terhadap Tekanan Darah Normal LakiLaki Dewasa." Jurnal Universitas Muhammadiyah Surakarta 1(4).

Sulastri. 2016. "Perawatan Hipertensi Dengan Labu Siam Terhadap Penurunan Tekanan Darah Hipertensi Pada Wanita Di Puskesmas Balongan Indramayu." Jurnal Care 4(3).

Sundari. 2016. Asuhan Kebidanan I (Kehamilan). Jakarta: Trans Info Media.

WHO. 2018. "Hipertensi Di Dunia." Http://Www. Who.Int/En/Hypertension.

Zakiah, Nan. 2012. "Beberapa Faktor Penyebab Terjadinya Hipertensi Pada Ibu Hamil Di Rumah Sakit Khusus Daerah Ibu Dan Anak Siti Fatimah Makassar." Ejournal.Medistra.Ac.Id, Diakses Tanggal 12 Januari 2020. 